\section{Succinic Dehydrogenase in Protozoa}

There is, as yet, relatively little information about the occurrence of individual enzymes in Protozoa. We have been successful in demonstrating the presence of a succinic dehydrogenase in homogenates of Paramecium caudatum. This has been done using a modified Cartesian diver respirometer of macro dimensions $(40-60 \mu \mathrm{l}$. total volume).

Three-day cultures were concentrated and freed from bacteria by a process of electrically directed migration followed by centrifugation. Cell-structure in the suspension $\left(2-6 \times 10^{4}\right.$ organisms $/ \mathrm{ml}$.) was destroyed by grinding for two minutes between ground-glass surfaces at $0^{\circ} \mathrm{C}$. The resulting homogenate was brought to $p \mathrm{H} 7 \cdot 2$ with phosphate buffer and its oxygen uptake in the presence of succinic acid, methylene blue, and inhibitors was studied. The final concentrations used were: succinate, $0.05 M$; methylene blue, $0.5 \mathrm{mgm} . / \mathrm{ml}$.; phosphate buffer, $0.03 M$; malonate, $0.08 M$; cyanide and azide, $0.01 M$; The $Q$ 's ( $\mu$ l. oxygen $/ 10^{4}$ organisms/ hour) are set out in Table 1 .

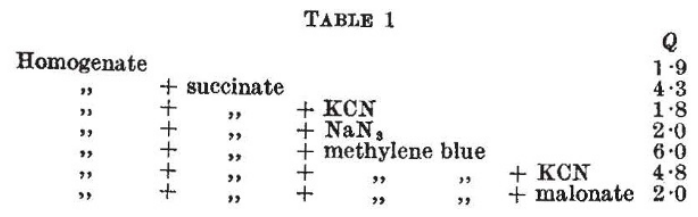

These results show that succinate doubles the endogenous oxygen uptake, and that cyanide or azide abolishes this increase. In the presence of succinate, methylene blue produces a further increase, and is able to offset the cyanide inhibition. Malonate completely abolishes the increase of oxygen uptake which is caused by succinate.

For comparison, Table 2 shows the effect of some of these factors on the endogenous respiration.

TABLE 2

\begin{tabular}{|c|c|c|}
\hline Homogenate & & $\underset{1}{Q} \cdot 9$ \\
\hline ", & $+\mathrm{KCN}$ & 0.8 \\
\hline ", & $+\mathrm{NaN}_{8}$ & $1 \cdot 1$ \\
\hline ", & + methylene blue & 1.9 \\
\hline
\end{tabular}

From these tables it follows that cyanide inhibits the endogenous respiration by 56 per cent and the extra respiration due to succinate by 58 per cent. The corresponding figures for azide are 44 and 63 per cent. Failure of methylene blue to stimulate the endogenous respiration of the homogenate may indicate lack of substrate or, conversely, a sufficient supply of carriers, in the original system.

While indicating that $P$. caudatum contains a succinic dehydrogenase essentially similar to that found in the Metazoa, the results have direct bearing on the question of cyanide-stability of respiration often reported in Protozoa, and should be interpreted in the light of the occurrence of cytochrome oxidase ${ }^{1}$.

The investigation will be published in full elsewhere.

\section{Beverley A. Humphrey GEORGE F. HUMPHREY}

Department of Biochemistry, University of Sydney. Dec. 16.

${ }^{1}$ Boell, Proc. U.S. Nat. Acad. Sci., 31, 396 (1945).

\section{Histological Distribution of Alkaline Phos- phatase in Helminth Parasites}

THE organisms used in this investigation were Ascaris lumbricoides, from the small intestine of the pig, and Moniezia expansa, from the small intestine of the sheep. They were brought to the laboratory in host gut contents contained in vacuum flasks and were fixed within two hours of the time of their removal from the host. The histological distribution

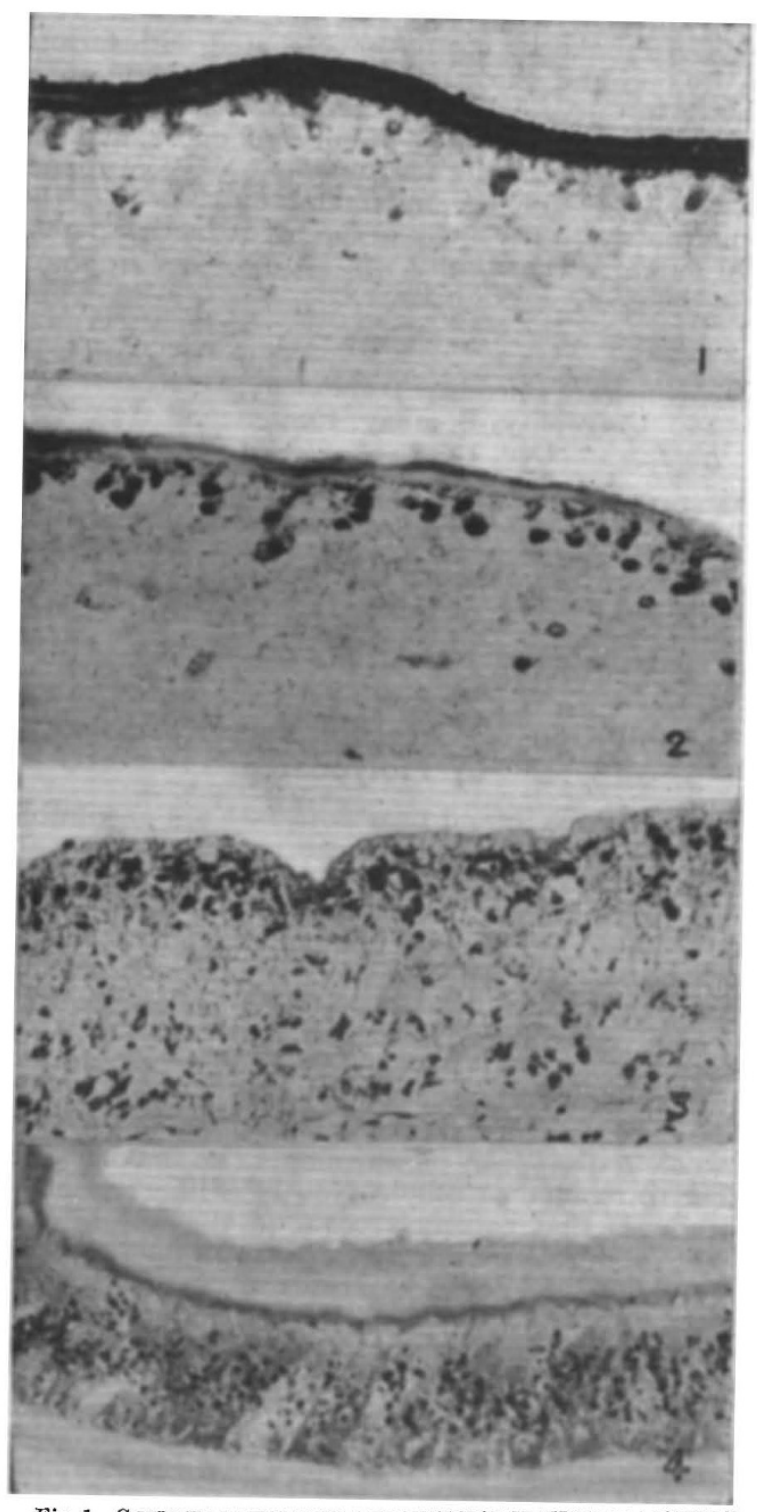

Fig. 1. CUTHCULAR REgION IN A TRANSVERSE SECTION OF A MATURE PROGLOTTID OF Moniezia expansa $(\times 400)$ STAINED FOR ALKALINE PHOSPHATASE. NOTE THE STRONG REACTION IN THE COTICULAR REGION

Fig. 2. CUTICULAR REGION IN A TRANSVERSE SECTION OF A MATURE SEGMENT OF Moniezia expansa $(\times 400)$ STAINED WITH HAMATOXYLIN-EOSIN BY THE USUAL METHODS

Fig. 3. CUTICULAR REGION IN A TRANSVERSE SECTION OF THF SCOLEX OF Moniezia expansa $(\times 400)$ STAINED FOR ALKALINE PHOSPHATASE. THE THICK 'CUTICLE' IS ABSENT AND THE PHOSPHATASE REACTION WAS NEGATIVE

Fig. 4. INTESTINE IN A TRANSVERSE SECTION OF Ascaris lumbricoides $(\times 400)$ TAKEN FROM ABOUT THE MID-POINT OF THE PARASITE. THE SECTION WAS STAINED FOR ALKALINE PHOSPHATASE,
THE SMALL BLACK BODIES IN THE INTESTINAL CELLS INDICATING THE POSITIVE REACTION 